\title{
A contact lens causing blood-stained tears
}

\author{
Sek Keung Kwok, ${ }^{1}$ Tommy Chung Yan Chan ${ }^{2}$
}

${ }^{1}$ Hong Kong Laser Eye Centre, Causewaybay, Hong Kong ${ }^{2}$ Hong Kong Eye Hospital, Hong Kong

\section{Correspondence to} Dr Sek Keung Kwok, skkwok@hotmail.com

Accepted 15 March 2016
CrossMark

To cite: Kwok SK, Chan TCY. BMJ Case Rep Published online: [please include Day Month Year] doi:10.1136/bcr-2016215025

\section{DESCRIPTION}

An 11-year-old girl presented with mild right upper lid swelling for 2 weeks, associated with mild inflammation. She was treated with topical antibiotics as a case of chalazion by her family physician. Unfortunately, the problem failed to respond to treatment and blood-stained tears were noted in the morning (figure 1 left). She was then referred to an ophthalmologist as well as a radiologist for imaging. Her mother had taken the patient to a private radiologist before visiting our ophthalmology department. CT scan of her orbital region demonstrated the presence of a $1 \times 0.45 \times 0.89 \mathrm{~cm}$ oval-shaped posterior eyelid lesion at the superomedial aspect of the right orbit (figure 1 right). There was a hypodense centre with fluid attenuation and a hyperdense rim. An infective focus or epidermoid cyst was suspected in the radiology report. At the ophthalmologist's office, the patient's upper lid was everted for examination-a rigid contact lens came out spontaneously (figure 2). Only then did her mother remember the loss of an orthokeratology lens 2 years prior. The swelling and blood-stained tears resolved shortly afterwards. A retained contact lens presenting as lid swelling is not uncommon in adults, and the mechanism of cyst formation has been described in the literature. ${ }^{12}$ The orthokeratology lens is a type of contact lens intended to slow myopic progression in children. ${ }^{3}$ This poses a challenge in making diagnosis as children may not be able to give a detailed history, and physical examination is more difficult. Imaging

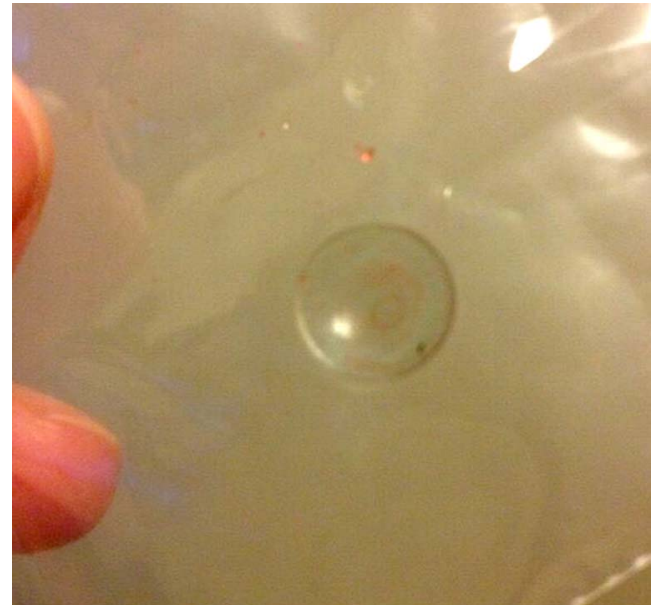

Figure 2 A retained orthokeratology contact lens was removed.

studies could be misleading if the history of a lost lens is not revealed.

\section{Learning points}

A retained contact lens can present as an eyelid mass or blood-stained tears.

- Eversion of the eyelid must be performed in all cases with an eyelid mass regardless of any contact lens wear history. 
Contributors SKK and TCYC had full access to all of the data in the study, and take responsibility for the integrity of the data and the accuracy of the data analysis. SKK and TCYC were responsible for study concept and design, and analysis and interpretation of the data. SKK was responsible for acquisition of the data. SKK and TCYC drafted the manuscript; and were responsible for critical revision of the manuscript for important intellectual content, and also for study supervision.

Competing interests None declared.

Patient consent Obtained.

Provenance and peer review Not commissioned; externally peer reviewed.

\section{REFERENCES}

1 Swarbrick H, Alharbi A, Watt K, et al. Myopia control during orthokeratology lens wear in children using a novel study design. Ophthalmology 2015;122: 620-30.

2 Hammons M, Gayre G, Hammons D, et al. Intrapalpebral migration of a rigid gas-permeable contact lens resulting in an eyelid mass. Ophthalmology 2003;110:1781-3.

3 Jones $\mathrm{D}$, Livesey $\mathrm{S}$, Wilkins $\mathrm{P}$. Hard contact lens migration into the upper lid: an unexpected lid lump. Br J Ophthalmol 1987;71:368-70.

Copyright 2016 BMJ Publishing Group. All rights reserved. For permission to reuse any of this content visit http://group.bmj.com/group/rights-licensing/permissions.

BMJ Case Report Fellows may re-use this article for personal use and teaching without any further permission.

Become a Fellow of BMJ Case Reports today and you can:

- Submit as many cases as you like

- Enjoy fast sympathetic peer review and rapid publication of accepted articles

- Access all the published articles

- Re-use any of the published material for personal use and teaching without further permission

For information on Institutional Fellowships contact consortiasales@bmjgroup.com

Visit casereports.bmj.com for more articles like this and to become a Fellow 